\title{
Epibiotic ciliates Scyphidia sp. and diatoms on Tigriopus fulvus (Copepoda: Harpacticoida) exoskeleton
}

\author{
Luigi Pane, Guido Bonello, Gian Luigi Mariottini \\ Department of Earth, Environment and Life Sciences, University of Genoa, Italy
}

\begin{abstract}
Several microorganisms - epibionts - can adhere to living supports taking advantage for their survival, feeding and movement. Epibiosis occurs particularly in aquatic environments, on both benthic and planktonic organisms, among which copepods and cladocerans represent an important living support. The harpacticoid copepod Tigriopus fulvus, living in the splashpools of rocky coasts, was studied to recognize the occurrence of epibionts on the exoskeleton surface using scanning electon microscopy techniques. The first evidence of ciliate Scyphidia sp. on Tigriopus fulvus has been described and the occurrence of algae Cocconeis sp. has been observed as well. Epibionts were found to adhere to antennae, a site linked to the exploitation of water currents carrying food particles to mouthparts and to swimming legs. The reason of the occurrence on swimming legs is less clear and needs further observations. Pertinent results are described and discussed and the influence of epibionts on life cycle and behavior of Tigriopus fulvus is considered.
\end{abstract}

Correspondence: Gian Luigi Mariottini, Department of Earth, Environment and Life Sciences, University of Genoa, viale Benedetto XV 5, 16132 Genoa, Italy.

Tel. +39.010 .3538049 - Fax: +39.010 .3538047 .

E-mail: Gian.Luigi.Mariottini@unige.it

Key words: epibiosis, ciliates, Scyphidia sp., copepods, Tigriopus fulvus.

Acknowledgements: special thanks are due to Reinhardt Møbjerg Kristensen, Curator at Natural History Museum of Denmark, for his cooperation in ciliate identification and to Giorgio Bavestrello (Department of Earth, Environment and Life Sciences, University of Genoa, Italy) and Rob McAllen (University College Cork, Ireland) who provided us with the specific bibliography.

Received for publication: 23 July 2014.

Revision received: 20 November 2014.

Accepted for publication: 20 November 2014.

(C) Copyright L. Pane et al., 2014

Licensee PAGEPress, Italy

Journal of Biological Research 2014; 87:4600

doi:10.4081/jbr.2014.4600

This article is distributed under the terms of the Creative Commons Attribution Noncommercial License (by-nc 3.0) which permits any noncommercial use, distribution, and reproduction in any medium, provided the original author(s) and source are credited.

\section{Introduction}

Epibiosis is an ecological relationship in which microorganisms, such as bacteria, fungi, algae, and protozoans, live attached to a living support, the basibiont, during all or single phases of their life cycle., Even though it is considered essentially as a commensal relationship, epibiosis can cause negative effects on the host, such as decrease of survival, growth and reproduction, motion difficulties, increase of predation pressure interfering with the escape capability and swimming of host, direct damage or induction of diseases, competition for food, increasing energy demands, susceptibility to predation and faster sinking rate. ${ }^{3-6}$ In particular, in food-limited environments ciliate epibionts can affect the survival of zooplankters, ${ }^{4,7}$ and decrease their fitness due to raised energetic demand for locomotion. ${ }^{8}$ Nevertheless, epibiosis can provide benefits to the basibiont, such as better availability of food and decrease of predation if epibionts are not attractive or repellent. The advantages for epibionts are mainly due to the possibility to be passively transported with obvious increase of feeding, enhancement of feeding rate $^{9}$ and food capturing efficiency, ${ }^{10}$ and decrease of predation. ${ }^{3,5}$

In aquatic environments, microorganisms can survive as free forms or by adhering to surfaces. ${ }^{11,12}$ The adhesion to living supports is thought to be extremely advantageous to epibionts which would be able to survive longer than free forms in stressful conditions. ${ }^{13}$ The microbial colonization of an organic substratum is a complex phenomenon originating from the initial random or chemotactic collision between microorganisms and surface, which results in the development of microorganisms on the surface itself.

Attached ciliates are common mainly on benthic organisms, ${ }^{14,15}$ but also the adhesion to phytoplankton and zooplankton as well as to suspended particles has been repeatedly reported. ${ }^{10,16,17}$ Some ciliates may attach and detach randomly without the intervention of specialized structures, ${ }^{18}$ but others produce stalks that allow them to better adhere to the surfaces. ${ }^{19}$ Copepods and cladocerans, being dominant in the zooplankton, are one of the main living supports providing attachment sites for a wide range of microorganisms that find abundant available binding surfaces on their exoskeleton. ${ }^{20-24}$ The occurrence of ciliate epibionts was recognized also on parasite copepods such as Lepeophtheirus salmonis, ectoparasite of marine salmonids. ${ }^{25}$ In particular, harpacticoids seem to be very important basibionts. ${ }^{2,26}$

Tigriopus fulvus Fischer is a harpacticoid copepod typical of supralittoral splashpools, a semi-confined environment characterized by wide seasonal and diel fluctuations of environmental conditions. ${ }^{27,28}$ Tigriopus fulvus has been extensively studied for reproduction, life cycle, ${ }^{29,30}$ ecology ${ }^{31}$ and at present is utilized as test-species in ecotoxicology. ${ }^{32-35}$ This copepod is known to host bacteria Vibrio alginolyti$c u s^{36}$ as well as diatoms on the exoskeleton surface. ${ }^{37}$ This paper describes the first scanning electron microscopy (SEM) evidence of ciliate epibionts on Tigriopus fulvus exoskeleton. 


\section{Materials and Methods}

Tigriopus fulvus specimens were sampled from splashpools along the Eastern Ligurian riviera (Genova Nervi, Ligurian Sea, Italy) by means of sterile bottles. Specimens were transferred in sterile seawater filtered with fiberglass filters and membrane filters Gelman GN/6 (0.45 $\mu \mathrm{m})$. In the laboratory copepods were maintained for a week at 30-32 PSU salinity, $8.0-8.3 \mathrm{pH}, 14^{\circ} \mathrm{C}$ and $12: 12 \mathrm{~h}$ light:dark period in a low temperature incubator (Haeraeus BK 6160), and fed with marine microalgae Tetraselmis suecica cultured as reported. ${ }^{38}$

For SEM observation ten specimens were carefully rinsed five times (3 min each) in sterile seawater, fixed with $4 \%$ buffered seawater formalin, dehydrated in ethyl alcohol gradients, dried in a critical-point drying apparatus, coated with gold in an ion-sputtering apparatus and observed with a Vega-3 LMU SEM (Tescan, Brno, Czech Republic).

\section{Results}

Scanning electron microscopy analysis revealed the occurrence of ciliates in one of examined specimens. They were subsequently classified at genus level as Scyphidia sp. Ciliates were found on swimming legs and antennae of a Tigriopus fulvus adult male (Figures 1 and 2). On the contrary, nine specimens did not show ciliate epibionts. Several adhered diatoms, presumptively belonging to the genus Cocconeis sp., as well as rod-shaped and coccoid bacteria were observed on the ventral region of a T. fulvus adult female (Figure 3).

\section{Discussion}

The utilization of SEM techniques allowed us to recognize the occurrence of epibiont protists (algae, protozoa, and bacteria) adhered to the splashpool copepod Tigriopus fulvus and to classify the ciliate epibionts as belonging to the genus Scyphidia.

It is known that ciliates may adhere to a wide range of surfaces among which freshwater and marine crustaceans are included. ${ }^{16,39-41}$ Some Scyphidia are known to occur in freshwaters and to colonize mainly copepods (57.14\% of the whole population), cladocerans and rotifers. ${ }^{5}$ Other species, such as Scyphidia ubiquita Hirshfield, have a littoral distribution and were recorded in the mantle cavity of snails Littorina sp. $^{42}$

Ciliate adhesion has been linked to copepod gender or developmental stage. As a matter of fact, in Indian lakes peritrich epibionts were found to adhere mainly to Mesocyclops aspericornis females $v s$ males or copepodids. ${ }^{41}$ Copepods Metridia longa and Paraeuchaeta norvegica collected in west Spitsbergen (Svalbard) were found to carry epibiotic ciliates Paracineta sp. which attached only to females. ${ }^{43}$ Utz and Coats ${ }^{44}$ stated that calanoid copepodids were more infested than adults suggesting a preference of epibionts for the attachment to juveniles. The observations reported here do not allow us to understand if the adhesion is more pronounced on males or females or if adhesion is more prevalent on adults or larval stages. To solve this question more numerous observations are needed.

Some ciliate epibionts were found to be selective for the attachment to different body regions. For example, the prosome of Mesocyclops aspericornis is the preferred site of epibiont adhesion. ${ }^{41}$ Other studies showed that the cephalothorax and the abdomen of calanoid copepods were more infested than antennae and swimming

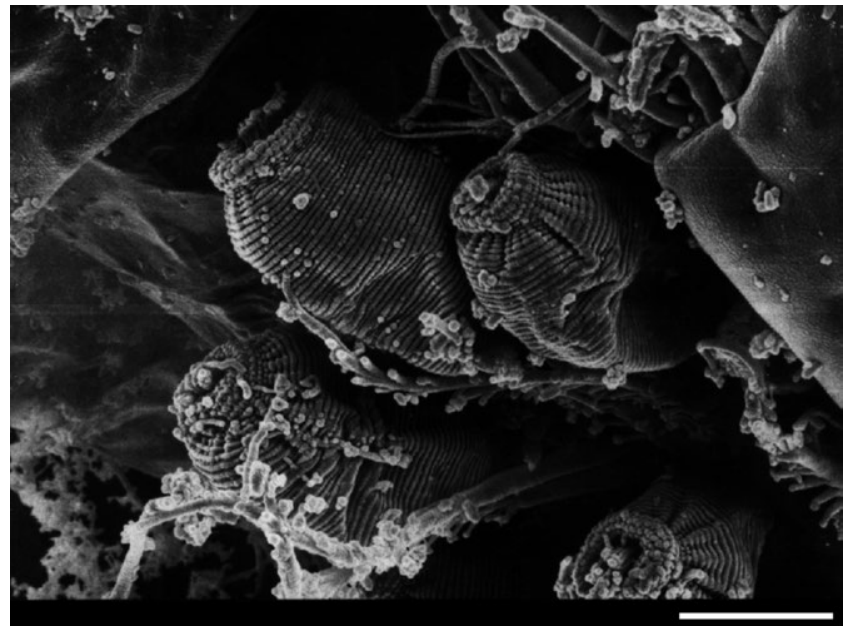

Figure 1. Ciliates Scyphidia sp. $(\mathrm{n}=4)$ on swimming legs of a Tigriopus fulvus adult male. Scale bar $=10 \mu \mathrm{m}$.

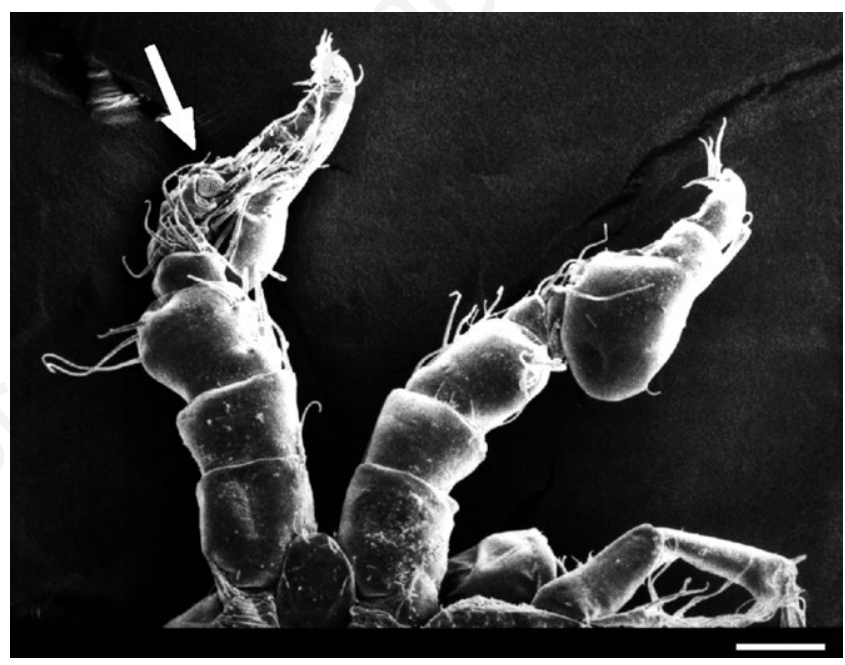

Figure 2. Ciliates Scyphidia sp. on antennae of a Tigriopus fulvus adult male. Arrow indicates the place of adhesion of the ciliate. Scale bar $=40 \mu \mathrm{m}$.

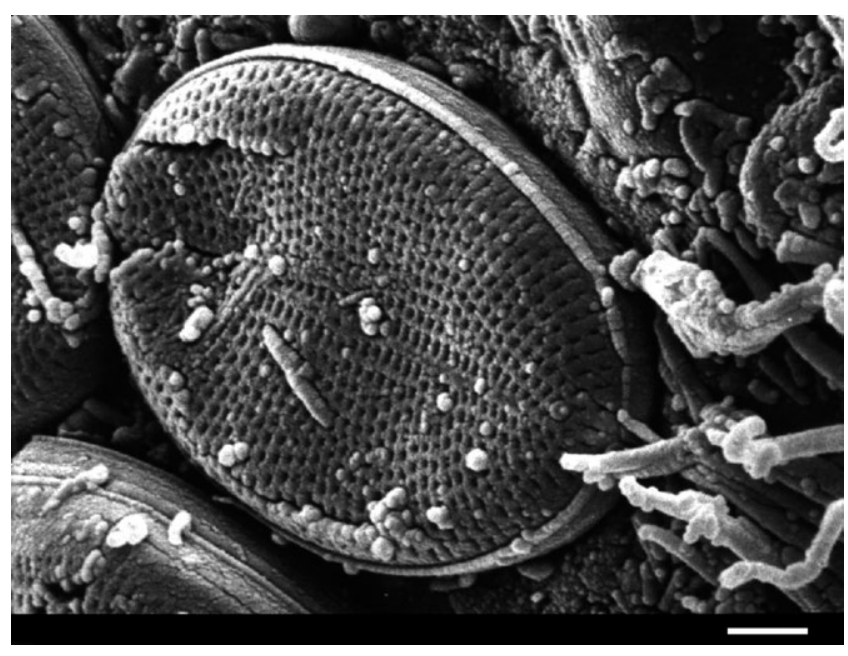

Figure 3. Pennatae diatoms $(\mathrm{n}=3)$ on Tigriopus fulvus female exoskeleton. Scale bar $=2 \mu \mathrm{m}$. 
legs indicating a preference of epibionts for less active parts of the host. ${ }^{44}$ On the contrary, our observations show the occurrence of Scyphidia epibionts on swimming legs and on antennae. As the choice of the site of adhesion is presumptively linked to an advantage that a site could provide in comparison to another one, the occurrence of epibionts on antennae has a reasonable significance since epibionts could better exploit water currents carrying food particles to mouthparts with a consequent improved feeding. Conversely, the reason of the occurrence on swimming legs where food availability is presumptively lower than near other body regions is less clear and needs further observations. Our observations partly disagree from those by Yamaguchi ${ }^{45}$ who reported that calanoid copepodids collected in subarctic Pacific, Japan Sea and Okhotsk Sea were seen to have no epibionts on antennules, feeding appendages and caudal rami and only a scarce presence on swimming legs (5\%) vs great numbers on the urosome (89\%), metasome (60\%), and cephalosome (19\%). Microbial epibionts, mainly bacteria (Leucothrix) but also peritrich ciliates and diatoms, the latter on swimming legs and furca, were described on the exoskeleton of adult, but not on copepodids, of Tigriopus brevicornis, a harpacticoid copepod whose habitat is analogous to that of Tigriopus fulvus. They were indicated presumptively to have effects on the movement and feeding of copepods; mouthparts and swimming legs were also heavily biofouled with ciliates that presumptively here take advantage of feeding currents. ${ }^{46}$

\section{Conclusions}

Ciliate epibionts associated with crustacean zooplankton are widespread in aquatic systems, but their ecological roles are poorly known. Further investigation is needed to study the occurrence, coverage and distribution of epibiosis on Tigriopus fulvus and to know how this ecological relationship could affect life cycle and behavior of this harpacticoid copepod.

\section{References}

1. Threlkeld ST, Chiavelli DA, Willey RL. The organization of zooplankton epibiont communities. Trends Ecol Evol 1993;8:317-21.

2. Fernandez-Leborans G, Chatterjee T, Grego M. New records of epibiont ciliates (Ciliophora) on Harpacticoida (Copepoda, Crustacea) from the Bay of Piran (Gulf of Trieste, Northern Adriatic). Cah Biol Mar 2012;53:53-63.

3. Wahl M. Marine epibiosis. 1. Fouling and antifouling: some basic aspects. Mar Ecol-Prog Ser 1989;58:175-89.

4. Xu Z, Burns CW. Effects of the epizoic ciliate, Epistylis daphniae, on growth, reproduction and mortality of Boeckella triarticulata (Thomson) (Copepoda: Calanoida). Hydrobiologia 1991;209:183-9.

5. Regali-Seleghim MH, Godinho MJL. Peritrich epibiont protozoans in the zooplankton of a subtropical shallow aquatic ecosystem (Monjolinho Reservoir, São Carlos, Brazil). J Plankton Res 2004;26:501-8.

6. Visse M. Detrimental effect of peritrich ciliates (Epistylis sp.) as epibionts on the survival of the copepod Acartia bifilosa. Est J Ecol 2007;56:173-8

7. Weissman P, Lonsdale DJ, Yen J. The effect of peritrich ciliates on the production of Acartia hudsonica in Long Island Sound. Limnol Oceanogr 1993;38:613-22.

8. Herman SS, Mihursky JA. Infestation of the copepod Acartia tonsa with the stalked ciliate Zoothamnium. Science 1964;146:543-4.
9. Shimeta J, Starczak VR, Ashiru OM, Zimmer CA. Influences of benthic boundary layer flow on feeding rates of ciliates and flagellates at the sediment-water interface. Limnol Oceanogr 2001;46:1709-19.

10. Christensen-Dalsgaard KK, Fenchel T. Increased filtration efficiency of attached compared to free-swimming flagellates. Aquat Microb Ecol 2003;33:77-86.

11. Colwell RR. Microbial ecology and biofouling. In: Colwell RR, Pariser ER, Siskey AJ, eds. Biotechnology in the marine sciences. New York, NY: Wiley Intersciences; 1981. pp 221-31.

12. Tamplin ML, Gauzens AL, Huq A, et al. Attachment of Vibrio cholerae serogroup 01 to zooplankton and phytoplankton of Bangladesh waters. Appl Environ Microb 1990;56:1977-80.

13. Roszak DB, Colwell RR. Survival strategies of bacteria in the natural environment. Microbiol Rev 1987;51:365-79.

14. Borror AC. Ecology of interstitial ciliates. Trans Am Microsc Soc 1968;87:233-43.

15. Fenchel T. The ecology of marine microbenthos. IV. Structure and function of the benthic ecosystem, its chemical and physical factors and the microfauna communities with special reference to the ciliated protozoa. Ophelia 1969;6:1-182.

16. Fernandez-Leborans G, Tato-Porto ML. A review of the species of the protozoan epibionts on crustaceans. I. Peritrich ciliates. Crustaceana 2000;73:643-83.

17. Šimek K, Jezbera J, Hornák K, et al. Role of diatom-attached choanoflagellates of the genus Salpingoeca as pelagic bacterivores. Aquat Microb Ecol 2004;36:257-69.

18. Jonsson PR, Johansson M, Pierce RW. Attachment to suspended particles may improve foraging and reduce predation risk for tintinnid ciliates. Limnol Oceanogr 2004;49:1907-14.

19. Randall JT, Hopkins JM. On the stalks of certain peritrichs. Philos T Roy Soc B 1962;245:59-79.

20. Hiromi J, Takano H. Preliminary note on pelagic marine copepods and their epizoic diatoms. Bull Plankton Soc Japan 1983;30:171-3.

21. Carman KR. Mechanisms of uptake of radioactive labels by meiobenthic copepods during grazing experiments, Mar Ecol-Prog Ser 1990;68:71-83.

22. Carman K, Dobbs FC. Epibiotic microorganisms on copepods and other marine crustaceans. Microsc Res Techniq 1997;37:116-35.

23. Bozkurt A, Genc E. First record of the epibiont protozoan Epistylis sp. on zooplankton (Copepoda, Cladocera, and Rotifera) from the Asi River, Turkey. Crustaceana 2009;82:515-30.

24. Bickel SL, Tang KW, Grossart H-P. Ciliate epibionts associated with crustacean zooplankton in German lakes: distribution, motility, and bacterivory. Front Microbiol 2012;3:243.

25. Fernandez-Leborans G, Freeman M, Gabilondo R, Sommerville C. Marine protozoan epibionts on the copepod Lepeophtheirus salmonis, parasite of the Atlantic salmon. J Nat Hist 2005;39:587-96.

26. Grigorovich IA, Dovgal IV, Maclsaac HJ, Monchenko VI. Acineta nitocrae: a new suctorian epizooic on nonindigenous harpacticoid copepods, Nitocra hibernica and $N$. incerta, in the Laurentian Great Lakes. Arch Hydrobiol 2001;152:161-76.

27. Carli A, Feletti M, Mariottini GL. Problemi di adattamento in ambienti confinati: Tigriopus fulvus Fischer (Copepoda, Harpacticoida). Biologi Italiani 1995;25:22-7.

28. Pane L, Mariottini GL. Characteristics of the rocky littoral system. Biological and ecological aspects. In: Macias B, Guajardo F, eds. Rock chemistry. Hauppauge, NY: Nova Science Publ.; 2010. pp 121-30.

29. Carli A, Mariottini GL, Pane L. Reproduction of the rockpools harpacticoid copepod Tigriopus fulvus (Fischer 1860), suitable for aquaculture. Bull Inst Oceanogr 1989;5:295-300.

30. Carli A, Mariottini GL, Pane L. Influence of nutrition on fecundity and survival in Tigriopus fulvus Fischer (Copepoda: Harpacticoida). Aquaculture 1995;134:113-9. 
31. Pane L, Feletti M, Carli AM. Fattori ambientali e fluttuazioni della popolazione del copepode Tigriopus fulvus delle pozze di scogliera di Genova-Nervi. In: Virzo De Santo A, Alfani A, Carrada GC, Flora A, eds. Proc. 7th National Congress of the Italian Society of Ecology, 1996 Sept 11-14, Naples, Italy. Ferrara: Italian Society of Ecology; 1996. pp 317-20.

32. Faraponova 0, De Pascale D, Onorati F, Finoia MG. Tigriopus fulvus (Copepoda, Harpacticoida) as a target species in biological assays. Meiofauna Marina 2005;14:91-5.

33. Pane L, Giacco E, Mariottini GL. Uso di Tigriopus fulvus (Copepoda: Harpacticoida) nella valutazione del rischio ecotossicologico in ambiente marino. Biol Mar Medit 2007;14:186-8.

34. Pane L, Mariottini GL, Lodi A, Giacco E. Effects of heavy metals on laboratory reared Tigriopus fulvus Fischer (Copepoda: Harpacticoida). In: Brown SE, Welton WC, eds. Heavy metal pollution. Hauppauge, NY: Nova Science Publ.; 2008. pp 157-65.

35. Pane L, Giacco E, Corrà C, et al. Ecotoxicological evaluation of harbour sediments using marine organisms. J Soils Sediments 2008;8:74-9.

36. Carli A, Pane L, Casareto L, et al. Occurrence of Vibrio alginolyticus in Ligurian coast rockpools (Tyrrhenian Sea, Italy) and its association with the copepod Tigriopus fulvus (Fischer 1860). Appl Environ Microb 1993;59:1960-2.

37. Pane L, De Nuccio L, Pruzzo C, Carli A. Adhesion of bacteria and diatoms to the exoskeleton of the harpacticoid copepod Tigriopus fulvus in culture: electron and epifluorescent microscope study. J Biol Res-Boll Soc It Biol Sper 2000;76:37-42.
38. Pane L, Feletti M, Bertino C, Carli A. Viability of the marine microalga Tetraselmis suecica grown free and immobilized in alginate beads. Aquacult Int 1998;6:411-20.

39. Puckett GL, Carman KR. Ciliate epibiont effects on feeding, energy reserves, and sensitivity to hydrocarbon contaminants in an estuarine harpacticoid copepod. Estuaries 2002;25:372-81.

40. Cabral AF, Dias RJP, Utz RP, et al. Spatial and temporal occurrence of Rhabdostyla cf. chironomi Kahl, 1933 (Ciliophora, Peritrichia) as an epibiont on chironomid larvae in a lotic system in the neotropics. Hydrobiologia 2010;644:351-9.

41. Rajabunizal K, Ramanibai R. Presence of an epibiont Epistylis niagarae (Protozoa Ciliophora) on Mesocyclops aspericornis in Velachery Lake Chennai India. J Biol Sci 2011;11:189-95.

42. Fish JD, Goodwin BJ. Observations on the peritrichous ciliate Scyphidia ubiquita from the west coast of Wales and a description of a new species. J Zool 1976;179:361-71.

43. Walkusz W, Rolbiecki L. Epibionts (Paracineta) and parasites (Ellobiopsis) on copepods from Spitsbergen (Kongsfjorden area). Oceanologia 2007;49:369-80.

44. Utz LRP, Coats DW. Spatial and temporal patterns in the occurrence of peritrich ciliates as epibionts on calanoid copepods in the Chesapeake Bay, USA. J Eukaryot Microbiol 2005;52:236-44.

45. Yamaguchi A. Suctorian ciliate epibionts on calanoid copepods in the subarctic Pacific. Bull Plankton Soc Japan 2006;53:29-36.

46. McAllen R, Hannah F. Biofouling of the highshore rockpool harpacticoid copepod Tigriopus brevicornis. J Nat Hist 1999;33:1781-7. 